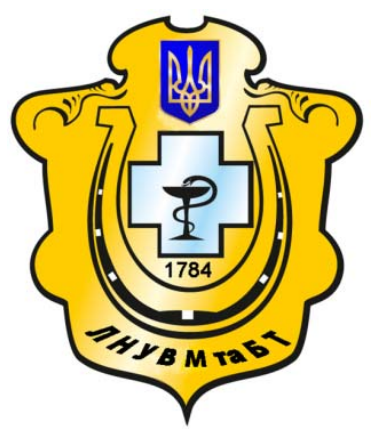

Науковий вісник Львівського національного університету ветеринарної медицини та біотехнологій імені С.З. Гжицького

Scientific Messenger of Lviv National University of Veterinary Medicine and Biotechnologies named after S.Z. Gzhytskyj

doi:10.15421/nvlvet7428

ISSN 2519-2698 print

ISSN 2518-1327 online

$\underline{\text { http://nvlvet.com.ua/ }}$

\title{
Продуктивність молодняку перепелів за використання у комбікормі різних джерел цинку
}

\author{
М.І. Голубєв, Т.А. Голубєва \\ golubev.mon@gmail.com \\ Наџіональний університет біоресурсів і природокористування Украӥни, \\ вул. Героїв Оборони, 15, м. Київ, 03041, Украӥна
}

\begin{abstract}
Наведено результати досліджень з встановлення оптимального джерела Цинку, який додатково вводять у комбікорми для перепелів, яких вирощують на м'ясо. Відповідно до схеми досліду, у добовому вічі було відібрано 300 перепелів, з яких сформовано три групи - контрольну та дві дослідні, по 100 голів (50 самищь і 50 самиів) у кожній. Були вивчені показники росту, збереженість та витрати комбікорму на 1 кг приросту маси тіла перепелів віком 1-35 діб залежно від рівня джерела Цинку у повнорачіонних комбікормах.

Встановлено, що більще корму споживали перепели, яким до комбікорму додавали органічні джерела Цинку, та за цим показником переважали контроль відповідно на 1,8-1,9\%. Збереженість поголів'я була досить високою у піддослідних групах і не залежала від джерела введеного Цинку. Додаткове введення птиці органічних джерел Цинку сприяє збільшенню кінцевої маси тіла при вирощуванні відповідно на 1,8-1,6\% $(P<0,05)$. В свою чергу найнижчі витрати корму на 1 кг приросту маси тіла були у перепелів, яким до складу комбікорму додавали гліцинат Цинку. Відмічено зв'язок між витратами корму та джерелом Цинку у комбікормі, який описується поліноміальною кривою з високим коефіцієнтом достовірності апроксимачіï $\left(R^{2}=1\right)$.
\end{abstract}

Ключові слова: перепела, маса тіла, витрати корму, відносні прирости, збереженість, комбікорм, джерела Цинку.

\section{Продуктивность молодняка перепелов за использования в комбикорме различных источников цинка}

\author{
М.И. Голубев, Т.А. Голубева \\ golubev.mon@gmail.com \\ Национальный университет биоресурсов и природопользования Украины, \\ ул. Героев Обороны, 15, Киев, 03041, Украина
}

\begin{abstract}
Приведены результаты исследований по установлению оптимального источника Цинка, который дополнительно вводят в комбикорма для перепелов, выращиваемых на мясо. Согласно схеме опыта, в суточном возрасте были отобраны 300 перепелов, из которых сформированы три группы - контрольную и две опытных, по 100 голов (50 самок и 50 самџов) в каждой. Были изучены показатели роста, сохранность и расходы комбикорма на 1 кг прироста массы тела перепелов 8 возрасте 1-35 суток в зависимости от уровня источника Цинка в полнорационных комбикормах.

Установлено, что больше корма потребляли перепела, которым в комбикорм добавляли органические источники Цинка, и по этому показателю преобладали контроль соответственно на 1,8-1,9\%. Сохранность поголовья была достаточно высокой в подопытных группах и не зависела от источника введенного Цинка. Дополнительное введение птице органических источников Цинка способствует увеличению конечной массы тела при выращивании на 1,8-1,6\% $(P<0,05)$ соответственно. В свою очередь низкие затраты корма на 1 кг прироста массы тела были у перепелов, которым в состав комбикорма вводили глицинат Цинка. Отмечено связь между затратами корма и источником Цинка в комбикорме, который описывается полиномиальной кривой с высоким коэффициентом достоверности аппроксимации $(R 2=1)$.

ключевые слова: перепела, масса тела, затраты корма, относительные приросты, сохранность, комбикорм, источники Цинка.
\end{abstract}

Holubiev, M.I., Holubieva, T.A. (2017). The productivity of young quail at the usage of different sources of zinc in fodders. Scientific Messenger LNUVMBT named after S.Z. Gzhytskyj, 19(74), 127-130. 


\title{
The productivity of young quail at the usage of different sources of zinc in fodders
}

\author{
M.I. Holubiev, T.A. Holubieva \\ golubev.mon@gmail.com

\begin{abstract}
National University of Life and Environmental Sciences of Ukraine, Heroyiv Oborony Str., 15, Kyiv, 03041, Ukraine
\end{abstract}

In the article, results of researches on an establishment of an optimum source of Zinc are resulted. Zinc was additionally added mixed fodder for quails grown for meat. In the research laboratory of feed additives National University of Life and Environmental Sciences of Ukraine carried out the experiment. In accordance with to the scheme of the experiment were selected of 300 daily quails. Were formed three groups - control and two experimental, 100 quails (50 females and 50 males) in each. Quails of the first group fed zinc sulfate, the second group - zinc glycinate, the third group - zinc citrate. Were studied indicators of growth, safety and the cost of feed per $1 \mathrm{~kg}$ increase in body weight daily quails ages 1-35 depending on the source of zinc in the mixed fodders.

It was found that more feed consumed quail, which was added to the mixed feeds of organic sources of Zinc. On this indicator, they dominated the control by $1.8-1.9 \%$. The preservation of quails was quite high in the experimental groups and did not depend on the source of Zinc. Additional introduction of organic sources Zinc increases the final body weight by 1.8-1.6\% $(P<0.05)$. The lowest feed costs per $1 \mathrm{~kg}$ of body weight gain were in quail, which included Zinc glycinate in the mixed fodder composition. The relationship between the cost of feed and fodder source of zinc $\left(y=0.011 x^{2}-0.037 x+3.147, R^{2}=1\right)$

Key words: quail, body weight, feed costs, relative increments, safety, mixed fodder, sources of zinc.

\section{Ветуп}

Цинк $є$ життєво необхідним мікроелементом для усіх сільськогосподарських тварин. Зважаючи на його участь у багатьох фізіологічних функціях організму (Vallee and Falchuk, 1993), додаткове введення Zn до раціону сільськогосподарських птахів стає все більш актуальним, що пов'язано $з$ надзвичайно швидким розвитком селекції та генетики у птахівництві, а також факторами, які впливають на його засвоєння (Lönnerdal, 2000; Sychov et al., 2016).

Цинк, зазвичай включається до раціону сільськогосподарської птиці у вигляді неорганічних і органічних сполук. Це пов'язано, насамперед, з незначним природнім вмістом Цинку у кормах рослинного походження та низькою його доступністю, що викликане зв'язуванням Zn 3 фітатними комплексами (Bao et al., 2007).

Зазвичай у кормах Цинк застосовуються у вигляді неорганічних солей - сульфатів та хлоридів. Такі сполуки технологічно виправдані для змішування при виробництві преміксів, однак, їх біологічна дія ускладнюється низькою засвоюваністю. Ці проблеми вирішуються за допомогою застосування органічних сполук, наприклад, 3 амінокислотами (Marchenkov and
Storozhuk, 2010; Star et al., 2012). Як показують наукові напрацювання у цьому напрямі, $\epsilon$ значні переваги використання саме органічних джерел $\mathrm{Zn}$. Однак більшість досліджень проведені на курчатах-бройлерах та курях несучках.

Тому актуальним $\epsilon$ 3'ясувати оптимальне джерело Цинку у комбікормі та встановити його вплив на продуктивність та витрати корму у перепелів, яких вирощують на м’ясо.

\section{Матеріал і методи досліджень}

Дослід проводили за методом груп в умовах науково-дослідної лабораторії кормових добавок Національного університету біоресурсів і природокористування України на молодняку перепелів породи фараон. Відповідно до схеми досліду у добовому віці було відібрано 300 добових перепелів, з яких сформовано три групи - контрольну та дві дослідні, по 100 голів (50 самиць і 50 самців) у кожній (табл. 1). При формуванні груп-аналогів враховували живу масу перепелів. Дослід тривав 35 діб і був розділений на два періоди (1-21 та 22-35 діб) та п’ять підперіодів, кожний 3 яких тривав 7 діб.

Схема науково-господарського досліду

\begin{tabular}{|c|c|c|}
\hline \multirow{2}{*}{ Група } & \multicolumn{2}{|c|}{ Характеристика досліджуваного елементу } \\
\cline { 2 - 3 } & Джерело & Вміст, мг/кг \\
\hline Контрольна: - перша & Сульфат Цинку & 75 \\
\hline Дослідні: - друга & Гліцинат Цинку & 75 \\
\hline - третя & Цитрат Цинку & 75 \\
\hline
\end{tabular}

Піддослідне поголів’я утримували в одноярусних кліткових батареях. Площа посадки з розрахунку на одну голову становила $73,5 \mathrm{~cm}^{2}$, фронт годівлі 1,5 см. Годували піддослідну птицю розсипними повнораціонними комбікормами, які роздавали двічі на добу (вранці та увечері), одночасно обліковуючи їх залишки, а напували - 3 вакуумних напувалок.
Упродовж досліду проводили облік збереженості поголів'я, вагового росту перепелів та обчислювали абсолютний, середньодобовий і відносний прирости їх живої маси, а також витрати кормів на 1 кг приросту.

Статистичну обробку даних здійснювали на ПЕ$\mathrm{OM}$ за допомогою програмного забезпечення MS 
Excel з застосуванням вбудованих статистичних функцій (СРЗНАЧ, СТАНДОТКЛОН, ТТЕСТ), а аналіз залежностей між досліджуваними факторами та показниками - побудови лінії тренду, визначенням рівняння регресії та коефіцієнту достовірності апроксимації $\left(\mathrm{R}^{2}\right)$.

\section{Результати та їх обговорення}

За даними таблиці 2, споживання комбікорму перепелами контрольної та дослідних груп упродовж кожного вікового періоду суттєво не відрізнялось, але спостерігались певні відмінності по групах.

Починаючи 3 першої доби вирощування птиця, у складі комбікорму якої містилися неорганічні джерела Цинку, споживала його більше за контроль на 0,4 1,3\% відповідно. Така тенденція спостерігається по всіх періодах вирощування. На кінець періоду вирощування найбільше комбікорму спожила птиця третьої групи, якій у складі комбікорму згодовували цитрат Цинку, та за цим показником перевищила контроль на $1,5 \%$.
За весь період досліду більше було спожито комбікорму птицею другої та третьої груп, яким до його складу додавали органічні джерела Цинку, що переважали контроль відповідно 1,8-1,9\%.

Таблицяя 2

\begin{tabular}{|c|c|c|c|}
\hline \multicolumn{4}{|c|}{ Споживання корму, кг } \\
\hline \multirow{2}{*}{ Вік, діб } & \multicolumn{3}{|c|}{ Група } \\
\hline & 1 & 2 & 3 \\
\hline $1-7$ & 4,75 & 4,77 & 4,81 \\
\hline $8-14$ & 15,74 & 15,92 & 16,07 \\
\hline $15-21$ & 22,27 & 22,92 & 22,95 \\
\hline $22-28$ & 30,56 & 31,31 & 31,03 \\
\hline $29-35$ & 35,82 & 36,15 & 36,34 \\
\hline $1-35$ & 764,0 & 777,5 & 778,4 \\
\hline
\end{tabular}

Залежно від використаного джерела Цинку у комбікормах змінювалася маса тіла піддослідної птиці. Так, якщо у перші три підперіоди вирощування, маса тіла не мала вірогідної різниці, то починаючи з 22-ї доби змінювалась залежно від періоду росту (табл. 3).

Маса тіла перепелів, г

Таблиця 3

\begin{tabular}{|c|c|c|c|}
\hline \multirow{2}{*}{ Вік, діб } & \multicolumn{3}{|c|}{ Група } \\
\cline { 2 - 4 } & 1 & 2 & 3 \\
\hline 1 & $9,29 \pm 0,092$ & $9,32 \pm 0,104$ & $9,30 \pm 0,105$ \\
\hline 7 & $28,85 \pm 0,551$ & $28,97 \pm 0,501$ & $29,23 \pm 0,551$ \\
\hline 14 & $81,49 \pm 0,768$ & $82,78 \pm 0,800$ & $84,01 \pm 0,769$ \\
\hline 21 & $132,98 \pm 0,971$ & $134,98 \pm 0,925$ & $135,36 \pm 1,072$ \\
\hline 28 & $191,16 \pm 1,123$ & $194,69 \pm 1,198^{*}$ & $194,35 \pm 1,119^{*}$ \\
\hline * $>0,05$ порівняно 3 контрольною групою. & $244,63 \pm 1,274^{*}$ & $244,01 \pm 1,250^{*}$ \\
\hline
\end{tabular}

Перепели, яким згодовували у складі комбікорму гліцинат та цитрат Цинку переважали контроль за період 22-28 діб на 1,8-1,7\% ( $<00,05)$, а у період з 29-ї по 35-ту добу відповідно на 1,8-1,6\% (p<0,05). Це дає можливість стверджувати, що згодовування птиці органічних джерел Цинку сприяє збільшенню кінцевої маси тіла при вирощуванні.

Зміна маси тіла, що спостерігалася під час досліду, вплинула на відносні прирости у перепелів дослідних груп (рис. 1).

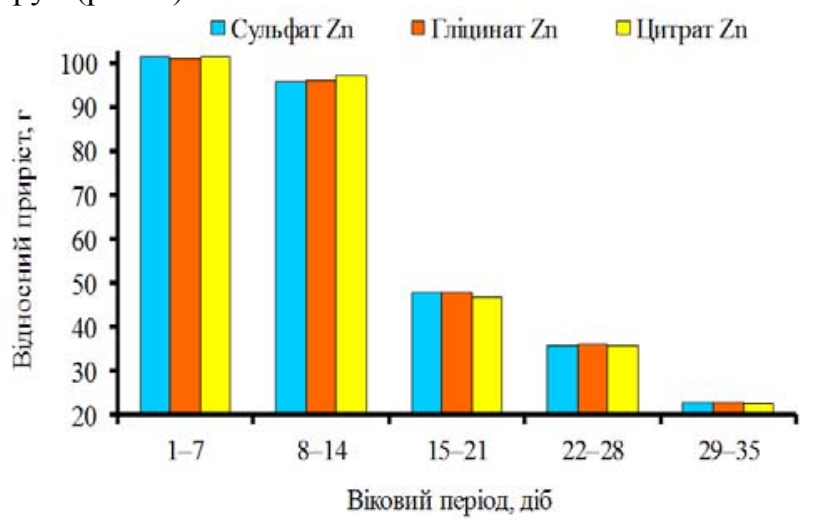

Рис. 1. Відносні прирости молодняку перепелів, г

У перший тиждень вирощування суттєвої різниці у відносних приростах між дослідними групами не спостерігалося. У другий тиждень - перепели, яким додатково вводили органічні джерела Цинку, переважали контроль за відносними приростами на 0,7$1,4 \%$. Найнижчий відносний приріст у третій тиждень вирощування спостерігався у молодняку перепелів третьої групи, з джерелом - цитрат Цинку, які за цим показником на 2,6\% поступалися птиці контрольної групи. При вирощуванні перепелів від 22- до 28добового віку найвищий відносний приріст виявлено у птиці другої групи, де він був порівняно з птицею контрольної групи вищим на $0,8 \%$.

Встановлено, що упродовж останнього періоду вирощування різниця між відносним приростом піддослідних перепелів була невелика, найінтенсивніше росли перепели другої групи, які за цим показником на $0,1 \%$ перевищували птицю контрольної групи.

Тому за весь період вирощування кращі відносні прирости мали перепели, яким додатково вводили гліцинат Цинку.

На збереженість перепелів значною мірою впливає біологічна повноцінність комбікорму, який використовують у годівлі птиці. Тому спостерігаючи за станом здоров'я піддослідної птиці, було проведено розрахунки збереженості поголів'я по періодах вирощування (табл. 4). Можна стверджувати, що птиця піддослідних груп мала досить непогані показники збереженості протягом всього вирощування. Найкращій він був у птиці третьої групи, якій до комбікорму додавали цитрат Цинку. 
Таблиияя 4

Збереженість поголів'я, \%

\begin{tabular}{|c|c|c|c|}
\hline Вік, діб & 1 & 2 & 3 \\
\hline $1-7$ & 97 & 97 & 98 \\
\hline $8-14$ & 97 & 97 & 98 \\
\hline $15-21$ & 97 & 97 & 98 \\
\hline $22-28$ & 97 & 97 & 98 \\
\hline $29-35$ & 97 & 97 & 98 \\
\hline
\end{tabular}

Спостерігається залежність між інтенсивністю росту молодняку перепелів та джерелом введеного Цинку, що позначається на витратах корму (табл. 5).

Витрати корму на 1 кг приросту маси тіла Табличя 5 перепелів, кг

\begin{tabular}{|c|c|c|c|}
\hline \multirow{2}{*}{ Вік, діб } & \multicolumn{3}{|c|}{ Група } \\
\cline { 2 - 4 } & 1 & 2 & 3 \\
\hline $1-7$ & 1,700 & 1,701 & 1,690 \\
\hline $8-14$ & 2,093 & 2,071 & 2,053 \\
\hline $15-21$ & 3,027 & 3,074 & 3,128 \\
\hline $22-28$ & 3,677 & 3,670 & 3,682 \\
\hline $29-35$ & 5,109 & 5,067 & 5,122 \\
\hline
\end{tabular}

Перепели, до складу комбікорму якого додавали цитрат Цинку, у перші два вікові періоди вирощування витрачали його на 1 кг приросту менше за ровесників контрольної групи відповідно на 0,6-1,9\%. У 15-21-добовомі віці найменші витрати корму спостерігаються у птиці контрольної групи, якій додавали сульфат Цинку, що на 1,6-3,3\% менше. Починаючи 3 четвертого періоду і до кінця вирощування перевага за цим показником була у перепелів другої групи, які до складу комбікорму отримуються гліцинат Цинку. Вони переважають аналогів контрольної та другої груп з 22 по 28 добу вирощування відповідно на $0,2-0,3 \%$, а з 29 по 35 добу на $0,3-0,8 \%$.

Встановлено зв'язок між витратами корму та джерелом Цинку у комбікормі, яка описується поліноміальною кривою з високим коефіцієнтом достовірності апроксимації (рис. 2).

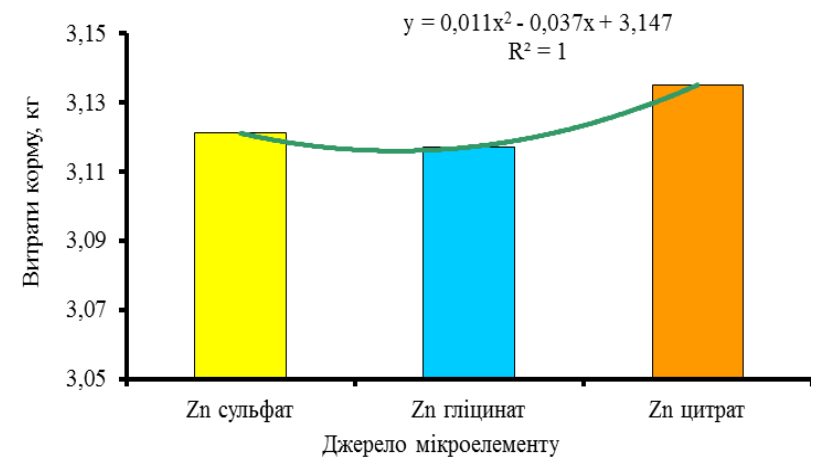

Рис. 2. Витрати корму на 1 кг приросту маси тіла перепелів, кг

Розрахунки витрат корму свідчать, що значної різниці між перепелами, яким згодовували комбікорм 3 додатковим введенням різних джерела Цинку не мало суттєвої різниці. Лише перепели 3 додатковим введенням гліцинату Цинку на 1 кг приросту маси тіла, витрачали його на $0,13 \%$ менше, порівняно $з$ тими, які споживали сульфат Цинку. Найбільші витрати корму були у перепелів, які споживали комбікорм з вмістом цитрату Цинку.

\section{Висновки}

За весь період досліду найбільше було спожито комбікорму птицею другої та третьої груп, яким до його складу додавали органічні джерела Цинку, що переважали контроль відповідно 1,8-1,9\%.

Встановлено, що упродовж останнього періоду вирощування різниця за відносними приростами між піддослідними групами була невелика, найінтенсивніше росли перепели другої групи, які за цим показником на $0,1 \%$ перевищували птицю контрольної групи.

Перепели до складу комбікорму, яких додавали гліцинат Цинку, за витратами корму переважали аналогів контрольної та другої групи 322 по 28 доби вирощування відповідно на $0,2-0,3 \%$, а з 29 по 35 добу на 0,3-0,8\%.

Встановлено зв'язок між витратами корму та джерелом Цинку у комбікормі, яка описується поліноміальною кривою 3 високим коефіцієнтом достовірності апроксимації $\left(\mathrm{R}^{2}=1\right)$.

В подальшому планується дослідити вплив різних джерел Цинку на перетравність корму та забійні показники перепелів, яких вирощують на м'ясо.

\section{Бібліографічні посилання}

Marchenkov, F.S., Storozhuk, T.V. (2010). Khelatni mikroelementy - vazhlyvyi komponent kombikormiv ta premiksiv. Zernovi produkty i kombikormy. 1, 3738 (in Ukrainian).

Sychov, M.Yu., Holubiev, M.I., Makhno, K.I., Pozniakovskyi, Yu.V. (2016). Mikroelementy u hodivli silskohospodarskoi ptytsi. K.: Komprint (in Ukrainian).

Star, L., Van Der Klis, J.D., Rapp, C., Ward, T.L. (2012). Bioavailability of organic and inorganic zinc sources in male broilers. Poultry Science. 91, 3115-3120.

Bao, Y.M., Choct, M., Iji, P.A., Bruerton, K. (2007). Effect of organically complexed copper, iron, manganese, and zinc on broiler performance, mineral excretion, and accumulation in tissues. The Journal Applied Poultry Research. 16(3), 448-455.

Lönnerdal, B. (2000). Dietary factors influencing zinc absorption. The Journal of Nutrition. 130, 1378-1383.

Vallee, B.L., Falchuk, K.H. (1993). The biochemical basis of zinc physiology. Physiological reviews. 73(1), $79-118$.

Стаття надійшла до редакиії 20.02.2017 